\title{
Aspectos geoambientais como subsídio ao planejamento urbano da cidade de Marabá (PA)
}

Savannah Tâmara Lemos da Costa

savannahlemos95@gmail.com

Universidade do Estado do Pará. Marabá. Pará. Brasil.

Layla Jasmim de Sousa Farias englaylafarias@gmail.com

Universidade do Estado do Pará. Marabá. Pará. Brasil.

Glauber Epifanio Loureiro epfanio@uepa.br Universidade do Estado do Pará. Marabá. Pará. Brasil.

\begin{abstract}
RESUMO
O crescimento populacional acompanhado do processo de urbanização nas cidades, tem intensificado a ocupação em locais cada vez mais adensados. Nesse sentido o objetivo deste estudo foi avaliar os aspectos geoambientais do perímetro urbano de Marabá-Pará para indicar as áreas adequadas à ocupação habitacional. Para tanto, utilizou-se informações espaciais processadas através de ESRI (2014), para elaboração dos mapas referentes aos aspectos geoambientais. Após isto, cada fator geoambiental foi submetido a Análise Hierárquica de Processos (AHP) em ambiente SIG. Como resultado, a compilação dos dados demonstrou que da totalidade do perímetro urbano de Marabá, 35\% da área é considerada favorável a ocupação habitacional. Deste percentual, a primeira opção de local mais adequado é a parte oeste da Zona de Expansão da Cidade Nova, onde verifica-se a predominância de áreas apropriadas, as quais representam $57,7 \%$ do total da zona. Apesar do núcleo São Felix também ser considerado adequado à habitação, a vulnerabilidade deste local se sustenta na planície fluvial, a qual é uma unidade geomorfológica fragilizada e característica de terrenos inundados. Nesse sentido, enfatiza-se a importância do estudo dos aspectos geoambientais paralelo ao planejamento urbano, com o intuito de minimizar a potencialização da fragilidade ambiental de áreas inapropriadas para ocupação habitacional.
\end{abstract}

PALAVRAS-CHAVE: Urbanização, aspectos físicos, Análise Hierárquica de Processos. 


\section{INTRODUÇÃO}

O crescimento populacional acompanhado do processo de urbanização nas cidades tem intensificado a ocupação em locais cada vez mais adensados. Este fato torna o ambiente mais vulnerável à degradação proveniente de atividades antrópicas. A procura dos indivíduos por melhor qualidade de vida, ou seja, oportunidade de emprego, serviço de saúde e educação, desencadeia a superlotação dos centros urbanos (FONTOURA, 2013).

Nesse sentido, esta problemática torna-se o cerne das desigualdades socioeconômicas e ambientais, decorrentes principalmente da falta de planejamento que resulta na modificação e transformação do espaço, com a ocupação de locais sensíveis e inapropriados como os fundos de vale ou vertentes em relevos de colinas, planícies e morros (SCHUTZER, 2012).

Diante do exposto, o estudo dos aspectos geoambientais que incluem o relevo, vegetação, hidrografia, altimetria, declividade, clima e uso do solo auxiliam no zoneamento de áreas de risco, proteção especial, ambiental e que podem ser habitadas. Sendo assim, estas caraterísticas físicas e ambientais são de suma importância para as fases de diagnóstico e prognóstico do planejamento ambiental (HONDA et al., 2015).

Ademais, ressalta-se que a combinação de informações geoambientais de um local pode ser realizada através da sobreposição de mapas temáticos, visto que este método possui o potencial de sintetizar e agrupar a situação ambiental de uma área geográfica específica e, assim, apresentar os potenciais ou limitações de um recurso natural (CREMONEZ et al., 2014). Desse modo, este procedimento efetiva-se por meio do geoprocessamento, o qual fornece tecnologias para processar e analisar informações espaciais, como as ferramentas do Sistema de Informação Geográfica (SIG) (BARBOSA; FURRIER; LIMA, 2013).

Portanto, a combinação dos fatores geoambientais com os sistemas de informações geográficas são instrumentos eficientes para o planejamento ambiental urbano de uma cidade, pois possibilitam o reconhecimento das vulnerabilidades apresentadas por um local por via de análise sistêmica da dinâmica espacial (COSTA; MORAES; PORTELA, 2015).

Partindo desta perspectiva, a cidade de Marabá é considerada como ponto estratégico, caracteriza-se como setor fronteiriço em virtude do fácil acesso à outras regiões brasileiras através das rodovias, hidrovias e uma ferrovia. Consolidou-se como receptora de grande contingente imigratório, especialmente na década de 70, com a descoberta de grandes depósitos minerais. Até os anos 80, houve crescimento populacional de $72 \%$ na cidade. As falhas na implantação de planejamento urbano para absorver o fluxo migratório, perduram até os dias de hoje e fomentaram ainda mais as ocupações informais (PONTES; CARDOSO, 2016).

Embora realizados estudos desde 1970, sobre a incapacidade do atual centro urbano de Marabá em comportar o contingente populacional resultante dos grandes projetos governamentais para a cidade, esta problemática persiste sem solução até os dias atuais. Isto é evidenciado pela falha de planejamento adequado e pelo déficit na prática da gestão do zoneamento de áreas, o que expõe comunidades inteiras a perigos decorrentes da má ocupação e uso do solo (ALMEIDA, 2008). 
Sendo assim, o objetivo deste trabalho foi avaliar os aspectos geoambientais do perímetro urbano de Marabá - Pará para indicar as áreas adequadas à ocupação habitacional, através do uso da Análise Hierárquica de Processos em ambiente SIG.

\section{REVISÃO DE LITERATURA}

\subsection{Planejamento urbano ambiental}

O planejamento urbano é um processo político-administrativo que norteia o desenvolvimento da malha urbana de uma cidade através da determinação de áreas ou zonas de acordo com seu uso e função. O principal intuito do planejamento consiste em articular, ordenar e equipar o espaço racionalmente (HONDA et al., 2015)

Nesse sentido, a Constituição Federal de 1988 estabeleceu em seus artigos 182 e 183 as diretrizes da política urbana, as quais determinam que o Poder Público municipal deve executar o ordenamento dos espaços da cidade, para que estes cumpram sua função urbanística e, assim, assegurar o pleno desenvolvimento urbano e a qualidade de vida da população (BRASIL, 1988).

Em 1992, as primeiras discussões acerca do desenvolvimento urbano sustentável, foram colocadas em pauta na Conferência "Rio-92", realizada no Brasil. A Agenda 21 foi um instrumento de planejamento criado neste período, com a finalidade de construir sociedades sustentáveis que utilizassem eficientemente os recursos naturais para o desenvolvimento econômico, sem causar prejuízos ao meio ambiente bem como promover qualidade de vida e equidade social (BARBOSA, 2008).

Para o planejamento sustentável das cidades brasileiras, isto é, adoção de políticas urbanas que não excluam as questões ambientais, o Congresso Nacional sancionou em 2001 a lei 10.257:2001, denominada Estatuto da cidade, a fim de regulamentar os artigos 182 e 183 da Constituição de 1988 (FONTOURA, 2013).

Dentre as diretrizes gerais estabelecidas neste instrumento legal, constam a garantia do direito a cidades sustentáveis, gestão urbana democratizada com participação da população e associações na formulação, execução e acompanhamento de planos, programas e projetos, cooperação entre setores públicos e privados para atender as necessidades da urbanização, planejamento e desenvolvimento das cidades, oferta de equipamentos urbanos e comunitários, assim como ordenação e controle do uso e ocupação do solo para evitar utilização inadequada do mesmo (BRASIL, 2001).

Nesse contexto, de acordo com o Ministério do Meio Ambiente, a qualidade de vida no processo de urbanização, está relacionada aos instrumentos do planejamento ambiental, os quais compreendem ao saneamento básico, direito à terra urbana, moradia, transporte e mobilidade, trabalho e lazer, além do Zoneamento Ecológico-Econômico (ZEE), Plano Diretor Municipal, Plano de Bacia Hidrográfica, Plano Ambiental Municipal, a Agenda 21 Local, e Plano de Gestão Integrada da Orla (MMA, 2016). 
O planejamento urbano ambiental é uma ferramenta chave para alcançar o desenvolvimento econômico e social de maneira sustentável, pois visa a eficácia na gestão e utilização de um território. As etapas de inventário e diagnóstico são primordiais para o reconhecimento das potencialidades e fragilidades da área, as quais norteiam a tomada de decisões com políticas públicas voltadas para a otimização dos recursos (ALBANO, 2013).

\subsection{Os aspectos geoambientais como suporte ao planejamento urbano}

A troca de energia e matéria no tempo e espaço constitui-se como fator modelador de paisagens, as quais ocorrem intrinsecamente em virtude dos aspectos geoambientais. Estes são compostos, segundo Costa, Moraes e Portela (2015), pela modelagem do relevo na qual incluem-se a declividade e altitude, cobertura vegetal, clima, corpos hídricos, litologia, pedologia e geomorfologia. Já Gomes e Pereira (2014) vão mais afundo, e elencam as formas de uso e ocupação das terras como aspecto geoambiental, em sua pesquisa de identificação de áreas fragilizadas no território brasileiro.

Dentro desse contexto, o termo "geoambiental" inicialmente foi adotado pela União Internacional de Ciências Geológicas para caracterizar os profissionais da área de geociências e meio ambiente, que buscavam aliar seus conhecimentos técnicos sobre o meio físico com os elementos de gestão ambiental. Isto é revelado por Silva e Dantas (2010), geógrafos do Serviço Brasileiro de Geologia - CPRM, em seu artigo sobre os objetivos e metodologias de mapeamentos geoambientais.

Os autores ainda agregam a este termo a utilização da cartografia, do Sistema de Informação Geográfica (SIG) e de bancos de dados como ferramentas de gestão. Tal perspectiva amplia o campo de atuação dos estudos geoambientais, os quais passam a ser fundamentais na estruturação de Plano Diretores Municipais, Zoneamento Ecológico-Econômico, construção de grandes projetos como oleodutos, aterros sanitários, hidrelétricas, na Avaliação de Impactos Ambientais, monitoramento de passivos ambientais entre outros.

Para Farias e Silva (2015), o estudo dos aspectos geoambientais se aplica na procura do ponto de equilíbrio do meio, frente às ações antrópicas, na tentativa de compatibilizar o uso de um recurso natural com a sua capacidade de suporte. Isto fica evidente na pesquisa dos autores, onde adotaram a bacia hidrográfica do Rio Palmeira no Ceará como unidade de gestão territorial, identificaram seus compartimentos geoambientais e analisaram a capacidade de uso dos mesmos com as atividades desenvolvidas. E com base nisto, detectaram que o inadequado manejo do solo com a ocupação desordenada e ausência de infraestrutura são potenciais degradadores e reforçam a incompatibilidade das atividades exercidas com as características naturais do meio físico.

Este cenário converge com o estudo realizado por Bastos, Cordeiro e Silva (2017) na serra de Baturité, onde as práticas realizadas são consideradas impactantes quando relacionadas ao quadro natural do local. Ou seja, o relevo juntamente com o regime de chuvas e a vegetação o configuram como espaço vulnerável às ações antrópicas e, desta forma, necessita de ordenamento territorial.

Seguindo esta ótica, Vidal e Mascarenhas (2017) utilizam dos aspectos geoambientais da cidade de Marabá/PA para a identificação e classificação das 
unidades geoecológicas do local. Nesta pesquisa, os autores correlacionam as unidades de paisagens delimitadas com os tipos de uso exercidos em cada uma delas. Assim, constatam que a mancha urbana vem se desenvolvendo em locais vulneráveis, sendo esta problemática, mais uma vez, o cerne das discussões do planejamento urbano das cidades.

Nesse sentido, a análise integrada da dinâmica entre fatores físicos, bióticos e abióticos, juntamente com a questão socioambiental, serve como subsídio para o planejamento ambiental, já que reconhecer as vulnerabilidades apresentadas em uma determinada área é importante para designá-la uma função que se enquadre a sua aptidão de uso. Este fato colabora na manutenção das comunidades e regulação da gestão dos recursos naturais (COSTA; MORAES; PORTELA, 2015).

\subsection{Geoprocessamento e ferramentas de suporte à decisão}

O geoprocessamento é definido como um conjunto de tecnologias que coleta dados e informações geograficamente referenciados, os armazena, manipula, analisa e os exibe para um objetivo específico. Além disso, é de caráter multidisciplinar e amplamente empregado em projetos e estudos ambientais por órgãos governamentais, não-governamentais e entidades privadas (FREITAS; BASSO; FERRI, 2015).

O Sistema de Informação Geográfica (SIG) é a principal ferramenta do campo do geoprocessamento por deter maior capacidade de processar e analisar informações espaciais. Nesse sentido, entende-se o SIG como processo cíclico no qual, primeiramente, há a aquisição de dados referentes ao mundo real, disponibilizados em bases do IBGE, INPE, CPRM e outros. Em seguida, os dados são introduzidos nos sistemas de software ou hardwares, os quais permitem o gerenciamento e armazenamento. Após isto, são submetidos à análise, por meio de técnicas de geoprocessamento, e por fim, são obtidas as informações que auxiliam na tomada de decisões para que uma ação seja escolhida, planejada e aplicada no mundo real. $\mathrm{O}$ produto final não resulta somente na produção de mapas e cartas, mas também em tabelas, gráficos e relatórios estatísticos (HAMADA; GONÇALVES, 2007).

Em consonância com o exposto, ao fazer referência a ferramenta SIG como auxílio na tomada de decisão, evidencia-se a análise multicritério como instrumento norteador, capaz de relacionar elementos pré-determinados em função de um objetivo. Nesse sentido, cabe salientar que a integração do geoprocessamento com os métodos multicritério, vem proporcionando inúmeros benefícios também para a resolução de problemas de planejamento urbano, quando há a relação coesa dos critérios selecionados, aos problemas que se deseja sanar ou simplesmente descobrir melhores alternativas (CASTRO et al., 2015).

Dentro dessa perspectiva, Cabral (2012) define a análise multicritério como recurso alternativo para resolução de problemas mediante a tomada de decisões, decorrente da análise dos critérios estabelecidos. Dentro desse contexto, é válido ressaltar que tal método, em especial o de Análise Hierárquica de processos (AHP), pode ser aplicado tanto para casos simples, como para aqueles que possuem alto grau de complexidade, como o auxílio na determinação da vulnerabilidade ambiental de uma bacia hidrográfica, por exemplo (PINESE JÚNIOR; RODRIGUES, 2012). 
Dentro desse contexto, o AHP foi desenvolvido por Tomas L. Saaty no início da década de 70 , e se constitui como o método multicritério mais amplamente utilizado e difundido, tendo como objetivo a seleção/escolha de alternativas, em um processo constituído a partir de diferentes critérios de avaliação. Dessa forma, deve-se inicialmente definir o problema, a necessidade e finalidade da decisão, além dos critérios a serem utilizados para a aplicação do método (SAATY, 2008).

Ainda de acordo com Saaty (2008), independente de sua aplicação, a Análise Hierárquica de Processos, divide-se basicamente em uma sequência analítica de três etapas, que seguem desde a dissolução do problema em uma estrutura de hierarquia (com objetivo, critérios e subcritérios e as alternativas), seguido da construção de uma matriz de comparação entre os critérios, utilizando a escala de importância de Saaty, até o cálculo do vetor de prioridade (classificação) para as alternativas. Sendo assim, Saaty (2000) enfatiza que o ser humano tem a capacidade de estabelecer relações coerentes entre objetos ou ideias, de modo que estas se relacionem de forma harmônica entre si e suas relações apresentem consistência.

\subsection{A cidade de Marabá e a expansão urbana}

A cidade de Marabá, no sudeste do Estado do Pará, originou-se em terras que abarcam a confluência entre dois rios, o Itacaiúnas e o Tocantins. Esta localização geográfica mostrou-se economicamente vantajosa nas décadas de 1920 e 1980, para a atividade extrativista de caucho e castanha-do-pará, porém imprópria para a ocupação e crescimento populacional, pois as condições topográficas não suportavam acomodar um aglomerado urbano estável (RUSSI, 2014).

Nesse sentido, a descoberta de grandes reservas minerais na região fomentou investimentos na cidade por intervenção do Governo Federal, o qual iniciou o processo de planejamento urbanístico para a mesma, com implantação de infraestrutura e outros equipamentos urbanos. Foi em 1970, que se criou o Plano de Expansão Urbana de Marabá (PEUM) a fim de adequar o espaço para o crescimento futuro, decorrente da chegada de grandes projetos. O bairro Nova Marabá foi uma das propostas deste plano, mas o seu insucesso de implantação, paralelo ao adensamento do núcleo Marabá Pioneira e ao surgimento de outros bairros como a Cidade Nova e o Amapá, contribuíram para a expansão desordenada, o que tornou outras áreas sujeitas a alagamentos (ALMEIDA, 2011).

Somente em 2006 foi determinado o macrozoneamento da cidade de Marabá, através do seu plano diretor - Lei 17.213:2006. A fim de controlar e direcionar o adensamento urbano, a sede municipal foi dividida em cinco distritos, dentre os quais estão Marabá Pioneira, Cidade Nova e Nova Marabá. Estes foram subdivididos em: zona central caracterizada por áreas de comércio, serviço e institucional; zona intermediária com predominância de residências e ocupações espontânea, pública ou privada; zona de expansão identificada pela infraestrutura insuficiente e processo de consolidação. Esta última não delimitada para o distrito Marabá Pioneira (MARABÁ, 2006).

Atualmente, Marabá detém posicionamento estratégico em virtude do entroncamento de estradas estaduais e federais, margem da estrada de Ferro Carajás e confluência entre rios. Desse modo, é ponto de conexão entre as demais regiões e estados brasileiros, fato que lhe torna setor fronteiriço (RUSSI, 2014). 


\section{MATERIAL E MÉTODOS}

\section{1 Área de estudo}

A área de estudo compreende ao perímetro urbano da cidade de Marabá, definido por Marabá (2009), e abrange os núcleos da Nova Marabá, São Félix, Nova Marabá, Marabá Pioneira e Cidade Nova; os Distritos Industriais Fase I, II e III e; as Zonas de Expansão da Cidade Nova e Nova Marabá (Figura 1). A cidade está localizada nas coordenadas 0521'54" ao sul e 49-07'24" a oeste e, segundo o panorama de cidades do IBGE (2018), a população estimada para o município no ano de 2018 foi de 275.086 habitantes.

Figura 1: Localização da área de estudo.

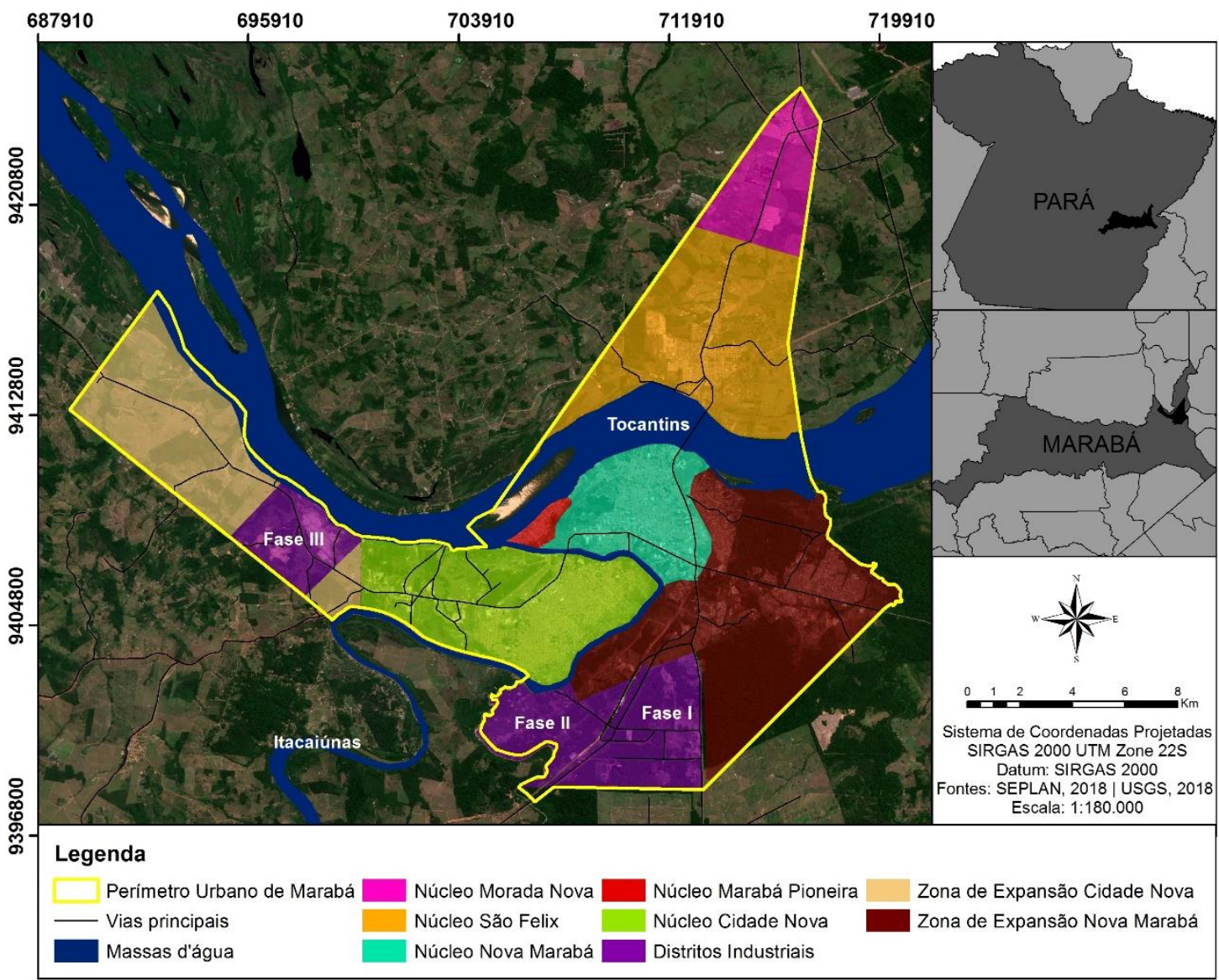

Fonte: Autoras (2018).

\subsection{Procedimentos metodológicos}

A metodologia adotada para a elaboração desta pesquisa foi a observativa, sistemática e indireta, com pesquisas bibliográficas e elaboração de inventário cartográfico. Os procedimentos seguiram três fases: organização e inventário, elaboração cartográfica e, diagnóstico, as quais foram estabelecidas por Farias e Silva (2015) e adaptadas para este estudo (Figura 2). 
Figura 2: Fases de execução dos procedimentos metodológicos.

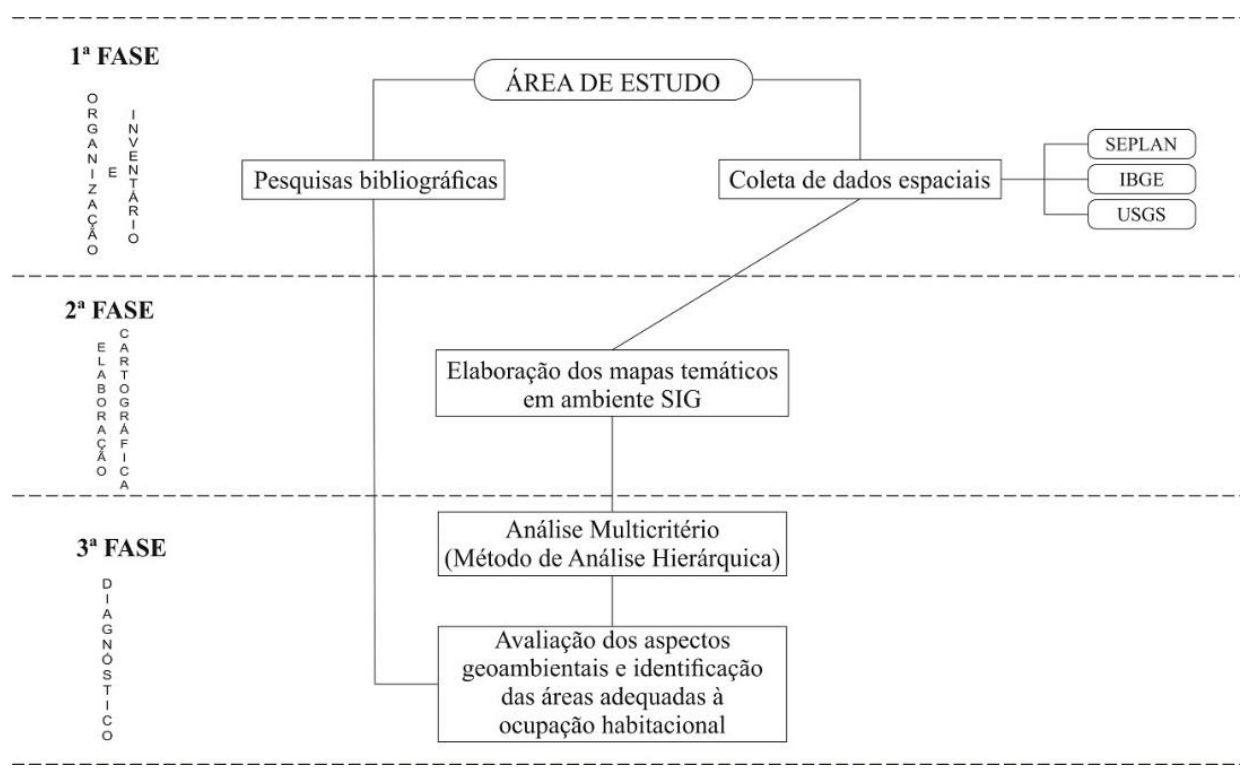

Fonte: Autoras (2018).

1a - ORGANIZAÇÃO E INVENTÁRIO

- Nesta primeira fase, pesquisou-se textos bibliográficos como artigos, livros, revistas científicas, legislações, dissertações, teses e outros. Para compor o inventário cartográfico adquiriu-se:

- Arquivos matriciais como a carta orbital da Missão Topográfica Radar Shuttle (SRTM, sigla em inglês) do tipo Modelo Digital de Elevação (MDE) com resolução de 30 metros (USGS, 2014); e imagem do satélite Sentinel, do ano de 2018, com resolução espacial de 10 metros, disponibilizados gratuitamente pelo Earth Explore do United States Geological Survey (USGS, 2018).

- Arquivos vetoriais correspondentes ao perímetro e núcleos urbanos do município, através da Secretaria de Planejamento de Marabá (SEPLAN, 2018).

- Arquivos vetoriais e dados da geomorfologia da área de estudo, disponibilizados gratuitamente pelo Geoserviço do Instituto Brasileiro de Geografia e Estatística (IBGE, 2018).

\section{2a - ELABORAÇÃO CARTOGRÁFICA}

Nesta segunda fase, efetivou-se a elaboração dos mapas temáticos dos aspectos geoambientais por meio do processamento de dados e metadados por meio de ESRI (2014) com aplicação de ferramentas de análise espacial.

Primeiramente, a partir do MDE, o mapa de altitude foi gerado por meio da modelagem da superfície terrestre com a criação do arquivo Triangulated Irregular Network (TIN), conforme Travalini e Cunha (2010). A declividade foi elaborada de acordo com Silva e Rodrigues (2009), e as classes foram definidas em seis: plano, suave ondulado, ondulado, forte ondulado, montanhoso e forte montanhoso (EMBRAPA, 1979). Em seguida, a renderização dos dados geomorfológicos compôs o mapeamento das unidades geomorfológicas (ESRI, 2014). 
A fim de tornar a imagem do satélite Sentinel útil à análise, executou-se a correção atmosférica da mesma através do método Dark Object Subtraction (CHAVEZ JÚNIOR, 1988), aplicado por meio de EXELIS (2013). Após isto, aplicou-se a classificação supervisionada por Máxima Verossimilhança para gerar o mapa de uso e ocupação do solo (SMITH, 2011). Também se utilizou a imagem para demarcar as Áreas de Preservação Permanente (APP) dos rios Itacaiúnas e Tocantins. Ao final dos processos, todos arquivos foram convertidos para tornarem aptos à execução da AHP.

\section{3a - DIAGNÓSTICO}

Nesta última fase, para realizar a análise multicritério utilizou-se o método de AHP (SAATY, 1980). Os critérios adotados dentro dos aspectos geoambientais foram declividade, altitude, geomorfologia, distância de rios e uso e ocupação do solo. Cada um destes foi definido com base nos aspectos legais (leis municipais, estaduais, federais) e técnicos (artigos científicos), a fim de indicar os parâmetros que revelam se um certo espaço possui características adequadas à ocupação.

Sendo assim, de acordo com a escala contínua de importâncias (Figura 3), foram atribuídas as importâncias e, por meio da matriz de comparação pareada, verificada a influência de cada critério para o objetivo da pesquisa.

Figura 3: Escala contínua de importâncias para matriz de comparação pareada.

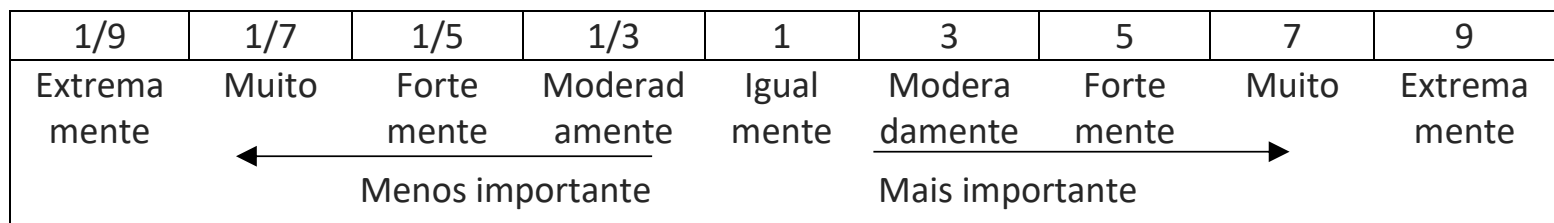

Fonte: Valente e Vettorazzi (2005).

Com base na escala contínua de Saaty (1980), adaptada por Valente e Vettorazzi (2005), e conforme a composição de cada aspecto geoambiental, atribuiu-se as importâncias na matriz de comparação pareada (Tabela 1).

Tabela 1: Matriz pareada com importâncias atribuídas.

\begin{tabular}{cccccc}
\hline Critérios & Declividade & Altitude & Geomorfologia & $\begin{array}{c}\text { Distância } \\
\text { de Rios }\end{array}$ & $\begin{array}{c}\text { Uso e } \\
\text { ocupação } \\
\text { do solo }\end{array}$ \\
\hline Declividade & $\mathbf{1}$ & 3 & $1 / 3$ & $1 / 5$ & $1 / 5$ \\
Altitude & $1 / 3$ & $\mathbf{1}$ & $1 / 5$ & $1 / 5$ & $1 / 5$ \\
$\begin{array}{c}\text { Geomorfologia } \\
\text { Distância de Rios }\end{array}$ & 3 & 5 & $\mathbf{1}$ & $1 / 3$ & $1 / 3$ \\
$\begin{array}{c}\text { Uso e ocupação } \\
\text { do solo }\end{array}$ & 5 & 5 & 3 & $\mathbf{1}$ & 3 \\
\hline
\end{tabular}

Fonte: Autoras (2018).

Por meio de ESRI (2014), os dados da matriz foram processados no algoritmo AHP, conforme aplicação de Marinone (2004), onde foram gerados os pesos de cada aspecto utilizados no produto final (Tabela 2). 
Tabela 2: Ponderações resultantes do método AHP.

\begin{tabular}{lc}
\hline Critérios & Pesos (\%) \\
\hline Declividade & 7,588 \\
Altitude & 4,572 \\
Geomorfologia & 15,89 \\
Distância de rios & 43,97 \\
Uso e ocupação do solo & 27,98 \\
\hline
\end{tabular}

Fonte: Autoras (2018).

Desta forma, o mapa final identificou os níveis de adequação para ocupação habitacional dentro do território urbano, através da multiplicação dos pesos de cada critério.

\section{RESULTADOS E DICUSSÕES}

O relevo Plano (0-3\%) e Suave Ondulado (3-8\%) predominam nos núcleos Morada Nova, São Félix, Marabá Pioneira e grande parte da Cidade Nova. Já o relevo Ondulado (8-20\%) e Forte Ondulado (20-45\%) concentram-se nos Distritos Industriais e nas Zonas de Expansão, sendo o forte ondulado de maior expressividade na Zona de Expansão Cidade Nova e Distrito Industrial Fase III, locais onde são identificadas as porcentagens mais altas, porém com valores abaixo de $30 \%$ (Figura 4).

Figura 4: Declividade do perímetro urbano de Marabá.

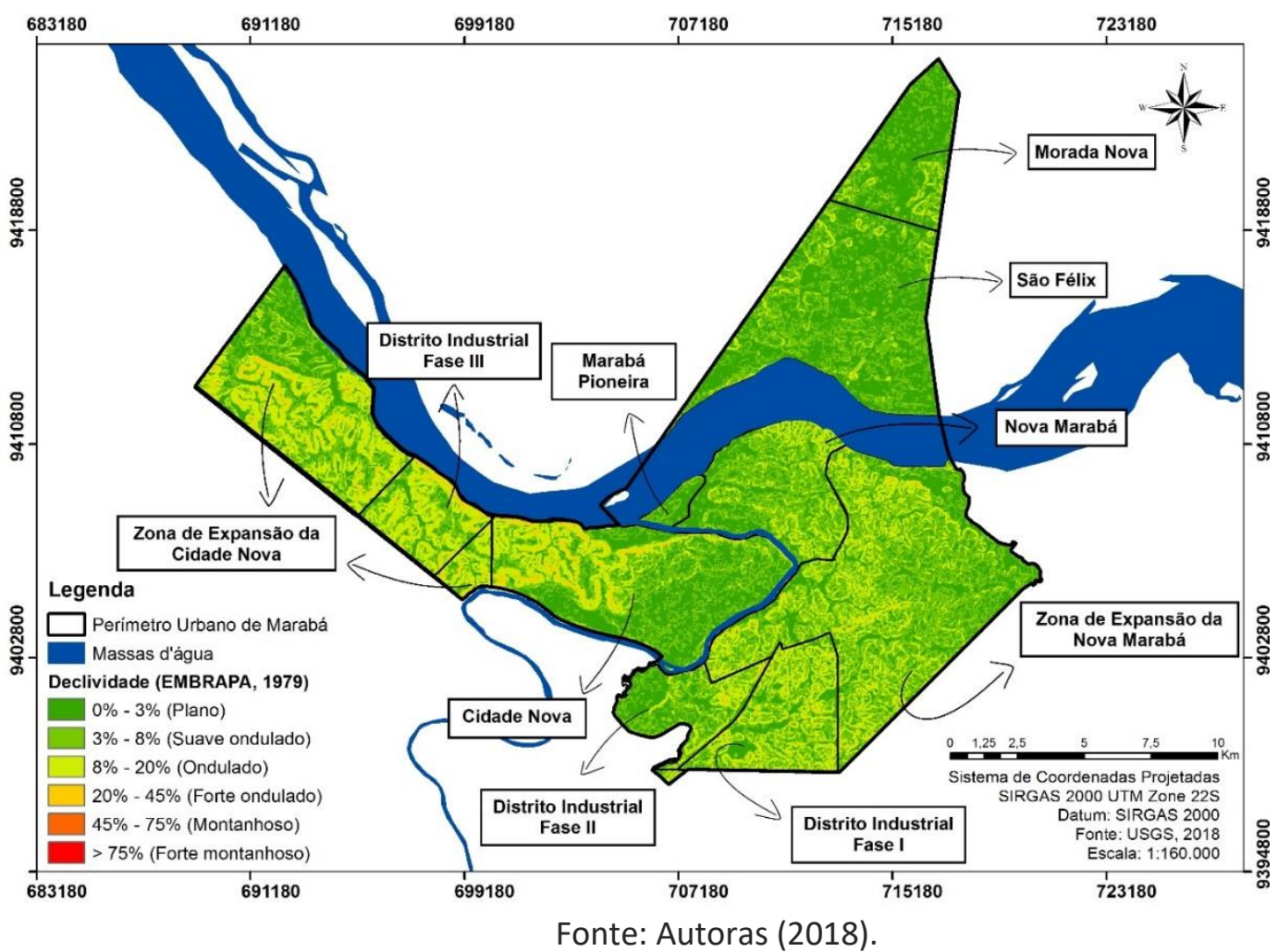


A declividade é um aspecto físico que influencia o transporte de sedimentos no solo. Locais menos declives como é o caso da Marabá Pioneira, Cidade Nova, São Félix e Morada Nova, tendem a receber maior carga de sedimentos e comumente são caracterizadas por planícies fluviais e/ou situam-se próximos a rios. Já os locais como as zonas de expansão, distritos industriais e Nova Marabá, em virtude de possuírem declividade acentuada, são responsáveis pelo aumento na velocidade dos fluxos dispersores, o que os tornam mais susceptíveis a erosão.

Nesse sentido, Sousa e Oliveira (2011), ao analisarem a declividade da bacia hidrográfica do córrego pedreira em Goiânia (GO), identificaram a mesma situação e destacaram que a susceptibilidade do terreno a processos erosivos pode ser intensificada devido ao manejo inadequado do solo.

São detectadas na zona de expansão da Nova Marabá ocupações irregulares em aclives e declives, as quais são definidas como setores de recuperação e qualificação, segundo Marabá (2006). Nestes locais, as ruas posicionam-se paralelas às declividades, este fato é diretamente proporcional a velocidade do escoamento superficial, e corrobora para a geração de sulcos no solo, principalmente naqueles desprovidos de cobertura vegetal.

Essa condição é fruto da falta de planejamento no local para receber as moradias. E, conforme demonstram Mascarenhas e Vidal (2014), uma vez não ajustada, torna-se determinante para ocorrência de erosões, o que tem colocado as edificações e seus eventuais moradores em situação de vulnerabilidade.

Apesar das zonas de expansão, distritos industriais e Nova Marabá apresentarem declividade acentuada e estarem sujeitos à erosão quando realizado o inadequado manejo, a porcentagem de declividade que caracterizam o relevo destas áreas enquadram-se nos limites, isto é, menor que 30\%. Segundo Brasil (1979) e Marabá (2018), não é permitido o parcelamento do solo para fins urbanos em áreas com declividade igual ou superior a $30 \%$.

Além disto, Brasil (2012) constitui como APP o topo de morros, montes, montanhas e serras, com altura mínima de 100 (cem) metros e inclinação média maior que $25^{\circ}$, aproximadamente $47 \%$. Sendo morro definido para esta constituição, de acordo com resolução CONAMA (2002), como elevação do terreno com cota do topo em relação a base entre 50 e 300 metros, e encostas com declividade superior a trinta por cento (aproximadamente dezessete graus) na linha de maior declividade.

Diante destes conceitos, em nenhum dos núcleos identifica-se locais com estas singularidades. No entanto, conforme Campos (2011), a impropriedade de ocupação de APP's com declividade superior a 30\%, justifica-se pela necessidade destas áreas para preservação dos recursos hídricos, da paisagem, do equilíbrio geológico, da biodiversidade, do fluxo gênico de fauna e flora, proteger o solo e assegurar o bem-estar das populações humanas.

Dentro dessa perspectiva, estes espaços são considerados como áreas frágeis, pois possuem baixa capacidade de se recuperarem quando atingidos por agentes antrópicos. Logo, a dificuldade em retornar ao seu estado de equilíbrio, tornam os ecossistemas potencialmente vulneráveis.

Em estudo realizado na serra de Baturité-CE, o desenvolvimento da agricultura em locais com declividade restrita, tem contribuído na intensificação dos processos erosivos e consequente assoreamento dos corpos d'águas situados 
morro abaixo (BASTOS; CORDEIRO; SILVA, 2017). Em vista disso, a fim de direcionar o uso do solo, seja para fim urbano ou rural, a identificação de relevos com limitações é imprescindível dentro da análise dos aspectos geoambientais.

No que se refere a altitude, o perímetro urbano de Marabá apresenta-se predominantemente com cotas altimétricas acima de 86 (oitenta e seis) metros, com exceção das áreas em torno dos corpos d'água, que apresentam cotas abaixo de 86 (oitenta e seis) metros e estão relevantemente localizadas nos núcleos Marabá Pioneira, Nova Marabá, Cidade Nova e São Félix (Figura 5).

Figura 5: Altitude, em metros, do perímetro urbano de Marabá.

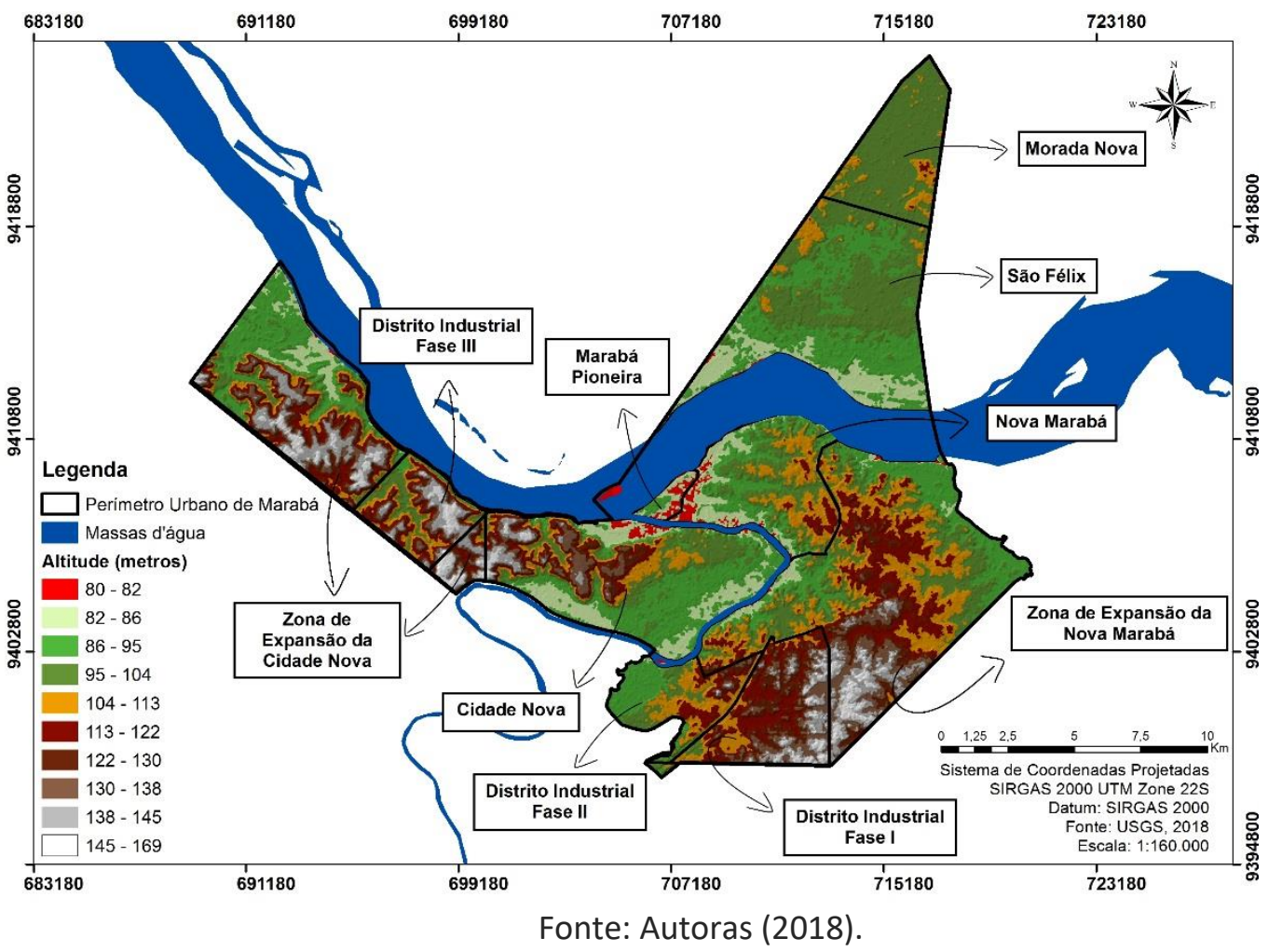

Dentro desse contexto, Marabá (2018) institui as áreas com cotas altimétricas abaixo de 82,00 (oitenta e dois) metros, como sendo parte constituinte das zonas especiais de interesse ambiental, devido ao contexto de vulnerabilidade ambiental, definido com base no histórico de inundações do município. Nesse sentido, a Marabá Pioneira é reflexo desta fragilidade, pois sua consolidação aliada as condições altimétricas desfavoráveis à ocupação, torna a população residente do núcleo alvo de eventos de inundação que ocorrem nos períodos mais chuvosos.

Um estudo realizado na área urbanizada da Bacia Hidrográfica do Ribeirão Lavapés em Botucatu - SP, demostrou que o terreno com altitudes entre 715 e 920 metros, apresentou baixo potencial natural de erosão e perda de solo, e que estes fatores estão associados a declividade e as características do tipo de solo (OLIVEIRA; SERAPHIM; BORJA, 2015).

Nessa perspectiva, a altitude encontrada na área de estudo possui cota máxima de 169 metros, destaca-se a Zona de Expansão Cidade Nova, isto é, aproximadamente 5 vezes menor quando comparada as altitudes da área urbana da Bacia Hidrográfica do Ribeirão Lavapés. Este dado designa que, as perdas de solo e potencial natural de erosão são baixos em locais onde estão demarcadas as 
zonas de expansão e os distritos industriais de Marabá. Todavia, vale ressaltar que as altitudes atuam em função da declividade, visto que regiões de baixas altitudes, porém de terreno bastante acidentado, podem acarretar deslocamentos de material sedimentar.

No que tange a formação geomorfológica do perímetro urbano de Marabá, verifica-se três unidades geomorfológicas, são elas: depressão do Médio e Baixo Araguaia, patamar dissecado Capim-Moju e a planície fluvial (Figura 6).

Figura 6: Unidades geomorfológicas que compõe o perímetro urbano de Marabá.

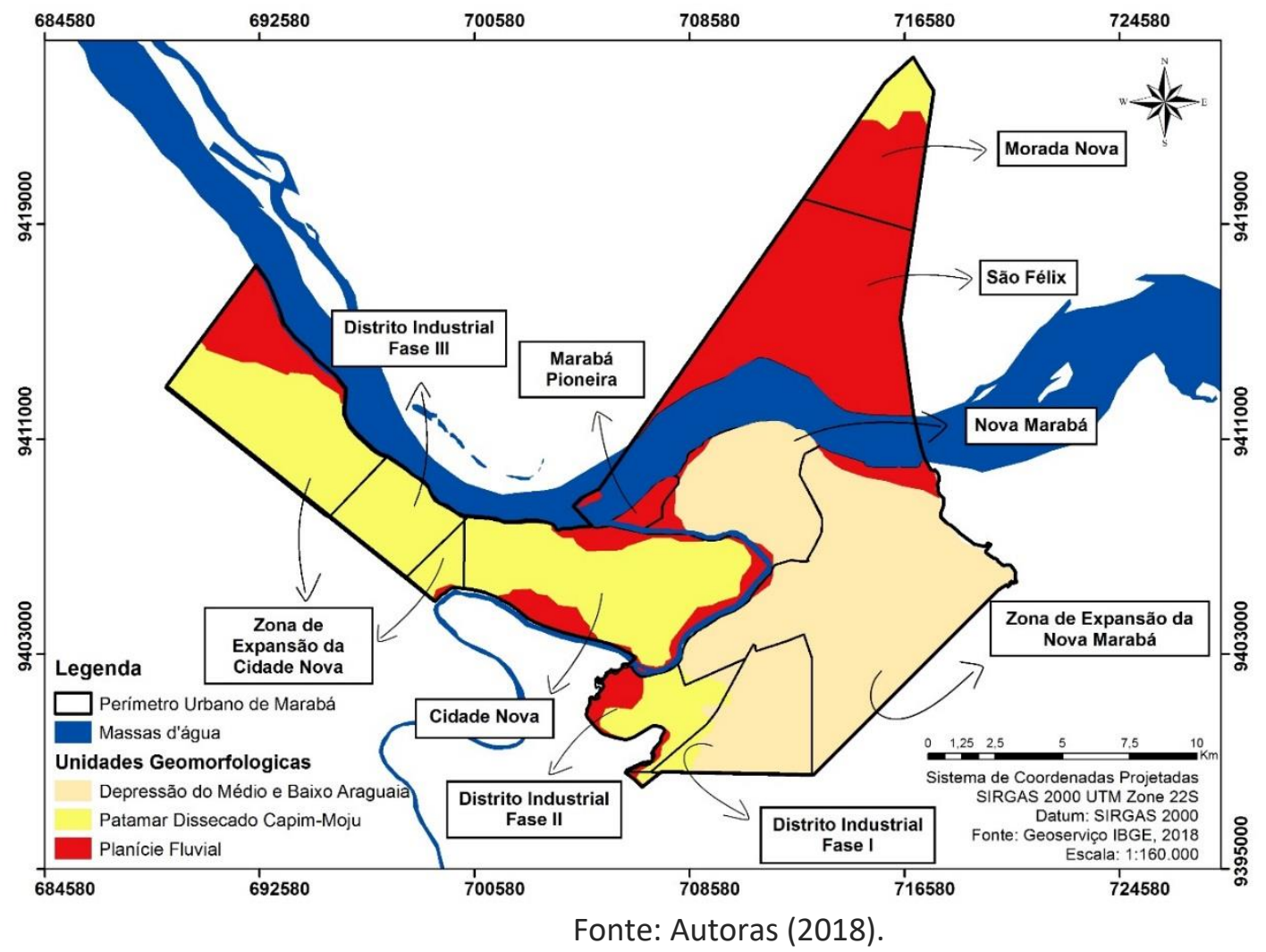

A depressão do médio e baixo Araguaia, apresenta-se com formações rochosas, com relevo que varia entre plano e dissecado e, cotas altimétricas que se situam em uma média de 200 metros. Além disto, nesta unidade, observa-se formas residuais, originadas por terrenos que se apresentam com maior resistência estrutural ao desgaste fluvial e pluvial (FURTADO; PONTE, 2013).

Dentro desse contexto, a depressão do médio e baixo Araguaia, abrange praticamente todo o núcleo Nova Marabá e Distrito Industrial Fase I, e totalmente a Zona de Expansão Nova Marabá. Neste último local, identificam-se fragmentos florestais de maior representatividade, como a Floresta Ombrófila Densa que compõe o Parque Zoobotânico de Marabá e a área militar do exército brasileiro. Já as áreas edificadas sustentadas por esta unidade, estão em maior escala dentro dos limites da Nova Marabá e são formadas por residências e comércios.

De acordo com Pará (2017), o Patamar Dissecado Capim-Moju caracteriza-se por relevo de topos convexos com vales pouco profundos e de vertentes de declividade suave. $\mathrm{Na}$ área de estudo, esta unidade garante ao relevo altitudes 
mais elevadas, assim, produz e direciona o fluxo de sedimentos e água para as áreas mais rebaixadas.

Nesse sentido, o patamar dissecado integra quase que totalmente o núcleo Cidade Nova e sua respectiva zona de expansão, e inclui as maiores cotas altimétricas. Quanto ao uso desenvolvido sobre a mesma, denota-se grande ocupação da malha urbana concentrada próxima ao rio Itacaiúnas, além disto, destaca-se as áreas de solo exposto, com vegetação secundária, alguns pontos com fragmentos florestais e instalações incipientes do Distrito Industrial Fase III de Marabá. Segundo Vidal e Mascarenhas (2017), embora as elevadas altitudes, o Patamar Dissecado em questão proporciona ambiente estável, todavia a ocupação deve ser realizada sob planejamento.

A unidade Planície Fluvial é designada pela acumulação de matéria e energia advinda dos pontos mais elevados do relevo, e decorrente da ação fluvial dos corpos hídricos. Segundo Farias e Silva (2015), possui solos férteis situados em áreas planas, bem como possui alta disponibilidade hídrica superficial e subterrânea, fato que contribui para a formação de um ambiente úmido.

Nesse sentido, a planície fluvial do território marabaense, além de margear os rios Tocantins e Itacaiúnas, integra a confluência dos mesmos, o que the proporciona maior dinamicidade. Em termos de urbanização, a unidade apresentase ocupada pela mancha urbana nos núcleos São Félix, Morada Nova e, principalmente, Marabá Pioneira e Cidade Nova.

Portanto, nestes locais a planície fluvial recebe influência direta das formas de uso do solo, como por exemplo na Marabá Pioneira e Cidade Nova, onde o elevado quantitativo de construções e pavimentação das ruas desencadeiam a impermeabilização da superfície e aceleram o escoamento superficial. Este aspecto, quando combinado as características da unidade, agrava a situação de inundações.

Sendo assim, embora possua solos férteis em virtude do recebimento de sedimentos, a planície fluvial carrega certo grau de fragilidade quanto à ocupação habitacional. Convergem para este pensamento Amaral e Ross (2009), pois ao estudarem a vulnerabilidade ambiental em Teodoro Sampaio - São Paulo, discutem que a planície está sujeita às inundações constantes, bem como à elevação do nível do lençol freático, e que, apesar da baixa declividade $(0-3 \%)$, é um ambiente frágil.

Na zona urbana de Marabá é notória a existência de extensas áreas que margeiam os rios Tocantins e Itacaiúnas. Denominadas de Áreas de Preservação Permanente (APP), estas exigem certo grau de diligência quanto a sua preservação, já que as matas ciliares atuam na conservação dos recursos hídricos, assim como na manutenção dos ecossistemas aquáticos e terrestres (Figura 7).

Nesse contexto, o rio Tocantins caracteriza-se como corpo d'água com largura maior que 600 metros, e o rio Itacaiúnas com largura entre 50 a 200 metros. De acordo com Brasil (2012), as faixas marginais designadas de APP destes rios são de 500 para o Tocantins e 100 metros para o Itacaiúnas. 
Figura 7: Delimitação das APP's dos rios Tocantins e Itacaiúnas na área urbana.

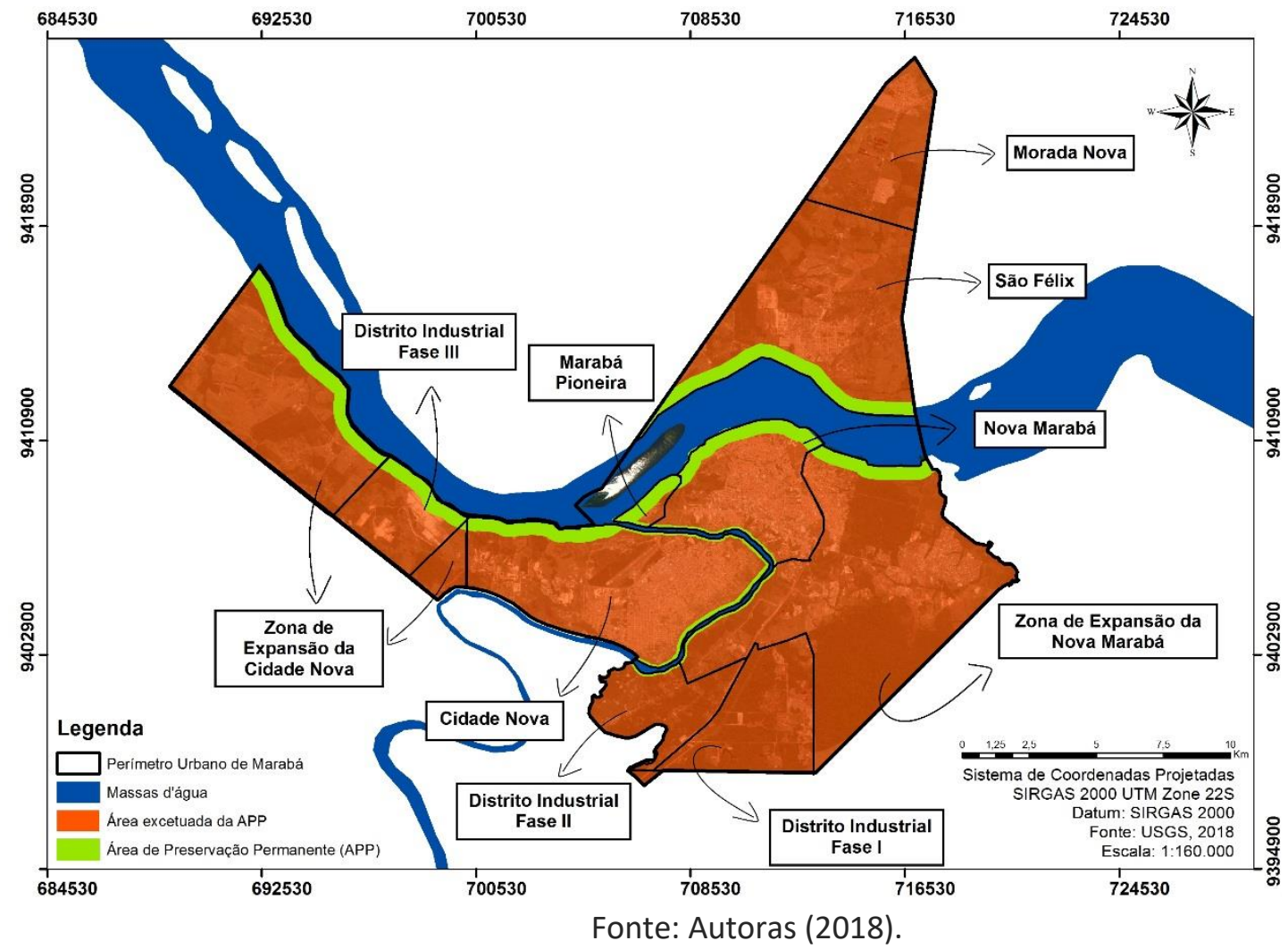

Sob essa ótica, o Novo Código Florestal ressalta a necessidade de proteger as APP's ao agregar maiores funções à mesma, como a preservação dos recursos hídricos, da paisagem, do bem-estar do ser humano, e a de assegurar a proteção do solo e do fluxo gênico de fauna e flora entre o ambiente aquático e terrestre. Esta carência é visível na maioria dos núcleos, exceto na Morada Nova e no Distrito Industrial Fase I, visto que as APP's não perpassam suas áreas.

Diante disto, Campagnolo (2013) converge com o disposto na legislação, ao discutir sobre as APP's como áreas de responsabilidade significativa na conservação dos taludes dos rios. Logo, agem como protetoras naturais da ocorrência de assoreamentos, pois atuam de forma ativa sobre o controle do escoamento superficial, na redução da velocidade do mesmo e na diminuição da carga sedimentar que, em condições adversas, seria carreada para o interior dos corpos d'água.

A recuperação das APP's da Marabá Pioneira, Cidade Nova e Nova Marabá, é necessária para que a presença de vegetação execute o processo de interceptação da água da chuva, a fim de proporcioná-la uma distribuição uniforme na superfície do solo. Segundo Alves (2015), a vegetação modifica a distribuição temporal e espacial das chuvas, diminui a quantidade de água que chega efetivamente ao solo, e desencadeia o abrandamento das cargas nas redes de drenagem e corpos receptores, além de serem fatores determinantes para o controle de enchentes e inundações.

Além disto, um estudo realizado por lelo (2015) no município de Ourinhos/SP destaca que, a ocupação inadequada de áreas frágeis e de baixa capacidade de recuperação, juntamente com a inexistência de planejamento, são potenciais 
causadores de grandes distúrbios como alagamentos, inundações e enchentes, os quais ocasionam perdas, não somente humanas e materiais, mas também ambientais.

Este cenário concatena com a situação de Marabá, onde espaços delimitados como APP e, em sua maioria sujeitos a riscos seja por suas condições topográficas ou pela ausência de redes de drenagem, estão totalmente habitados, destaca-se a Cidade Nova e Marabá Pioneira. Nestes locais, a ocupação se deu de forma irregular, desprovida de infraestrutura e de equipamentos necessários ao pleno desenvolvimento urbano. Tal fato, além de tornar o ambiente vulnerável, ameaça a qualidade dos recursos hídricos.

Há ainda quem se contraponha a isto, Monteiro (2012) afirma que, embora protegidas por lei, as APP's podem, por vezes, assumir o papel de agente limitante no que tange ao direito de construir, o qual se encontra incorporado ao direito de propriedade e, portanto, constitui-se em um direito fundamental protegido pela Constituição Federal.

Entretanto, Brasil (2012) concilia esta situação, ao permitir a remoção ou intervenção em APP quando a finalidade for de utilidade pública, de interesse social ou considerada de baixo impacto ambiental como abertura de pequenas vias de acesso, implantação de estruturas para captação de água e lançamento de efluentes tratados entre outras atividades previstas nesta mesma lei.

Esta situação contraditória é verificada no Distrito Industrial - Fase III, no qual as obras da siderúrgica Aços Laminados do Pará (ALPA) estão sendo realizadas sobre as APP's do rio Tocantins. Apesar disto, trata-se de um interesse econômico e social, e que necessita do recurso hídrico para utilização nos processos industriais e para a diluição de poluentes.

No tocante uso e ocupação do solo do perímetro urbano, detectou-se na paisagem quatro classificações. A primeira, integra os fragmentos florestais de vegetação nativa disponíveis. A segunda, engloba o solo exposto representado por espaços desnudos, isto é, sem cobertura verde. E por fim, a terceira e última classe formada pela área construída, consolidada ou em consolidação (Figura 8). 
Figura 8: Uso e ocupação do solo na área urbana de Marabá.

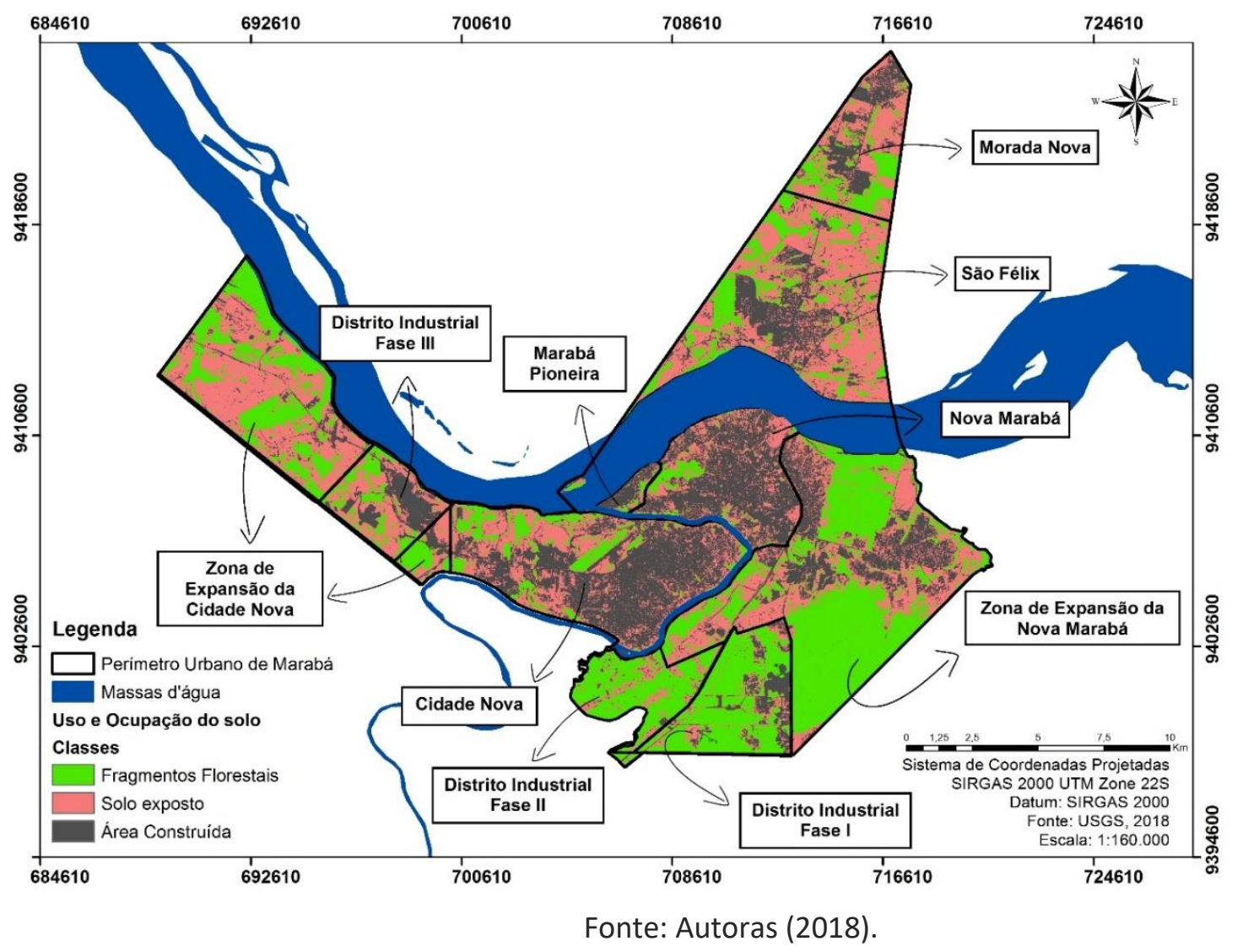

Nessa perspectiva, os remanescentes de vegetação nativa que compõem o espaço urbanizado são formados por pequenos pontos verdes em locais construídos, áreas militares preservadas, pelo Parque Zoobotânico de Marabá e por reservas florestais de propriedades rurais que se encontram dentro dos limites da cidade, a maior concentração destas áreas florestais está nas zonas de expansão e nos distritos industriais Fases I e II. De acordo com Schaadt e Vibrans (2015), estes fragmentos florestais são caracterizados como a divisão de florestas contínuas em fragmentos de menor extensão, isolados em uma matriz diferente do habitat original.

Cabe salientar que, a escassa conexão entre os fragmentos florestais das zonas de expansão com as áreas construídas, corrobora para a exposição dos remanescentes à diferentes condições climáticas, como a redução da umidade do ar, aumento da luminosidade e da temperatura, além da redução e o isolamento de populações de espécies, o que dificulta o fluxo gênico, podendo causar a perda da biodiversidade e até a extinção de componentes da fauna e flora. Assim, as alterações bióticas e abióticas que ocorrem, principalmente, no limite dos fragmentos também influem diretamente sobre a dinâmica da flora e fauna local.

Para Martini e Bioni (2015), apesar da ação antrópica sobre essas áreas e pela ausência da associação destas com outras áreas florestadas, os fragmentos florestais desempenham ainda forte função social, associada à melhoria na condição microclimática, amenização acústica, redução de poluentes atmosféricos, proteção do solo e sobrevivência da avifauna. Isto é perceptível na zona de expansão da Nova Marabá, em áreas de loteamento localizadas próximas 
ao Parque Zoobotânico e a área militar do $52^{\circ}$ BIS, onde é proporcionada aos habitantes uma melhor qualidade de vida e ambiental.

De acordo com Marabá (2006), as áreas construídas são divididas em setores, estes que foram delimitados conforme seu grau de consolidação e da infraestrutura básica instalada. O setor de uso consolidado abrange as zonas residenciais, comerciais, industriais e com infraestrutura básica instalada, enquanto que o setor em consolidação, além destas características citadas, integra terrenos com irregularidade fundiária. O setor de recuperação e qualificação inclui ocupações passíveis de regularização fundiária, assentamentos precários e locais sujeitos a riscos por inundação.

Diante do exposto, embora exista o macrozoneamento, Pontes e Cardoso (2016) afirmam que os centros urbanos são descontínuos, entrecruzados por espaços abertos e, portanto, prejudicam o equacionamento dos problemas atuais no que tange a instalação de sistemas de drenagem e saneamento básico.

Ademais, é possível identificar que a malha urbana se estende para além das APP's. Este fato, além de modificar potencialmente os sistemas naturais, dificulta a implantação da sustentabilidade na cidade. Portanto, os solos expostos verificados em especial nas zonas de expansão e no núcleo São Felix são os locais com disponibilidade para ocupações residenciais, desde de que o uso se demonstre compatível às características físicas do terreno.

A partir da compilação e posterior análise dos dados apresentados para cada aspecto geoambiental, verificou-se que a cota altimétrica abaixo de 82 metros, os fragmentos florestais, as APP's e a unidade geomorfológica planície fluvial são fatores limitantes à ocupação habitacional. Já os solos expostos, a declividade, os locais com altitude acima de 86 metros e as unidades Patamar Dissecado CapimMoju e Depressão do Médio e Baixo Araguaia são aspectos físicos que se mostram favoráveis a construção de habitações. Vale ressaltar, que estes três últimos aspectos estão intrinsecamente associados.

Nesse sentido, da totalidade do perímetro urbano de Marabá, 35 \% da área é considerada favorável a ocupação habitacional. Deste percentual, a primeira opção de local mais adequado é a parte oeste da Zona de Expansão da Cidade Nova, logo após o Distrito Industrial Fase III, onde verifica-se a predominância de áreas apropriadas, as quais representam $57,7 \%$ do total da zona, e são identificadas no mapa através da cor verde escura (Figura 9).

Em segundo lugar, o setor leste do núcleo São Felix também é considerado adequado a habitação, porém com características físicas menos propícias em detrimento da zona de expansão, tal fato é constatado por meio da cor verde menos intensa (Figura 9). Estes resultados, advêm da avaliação de cada critério e suas variações de forma isolada, onde a junção das melhores características de cada aspecto avaliado, corroboraram para a definição das melhores áreas em consonância com o objetivo proposto. 
Figura 9: Identificação dos locais adequados à ocupação no espaço urbanizado de Marabá.

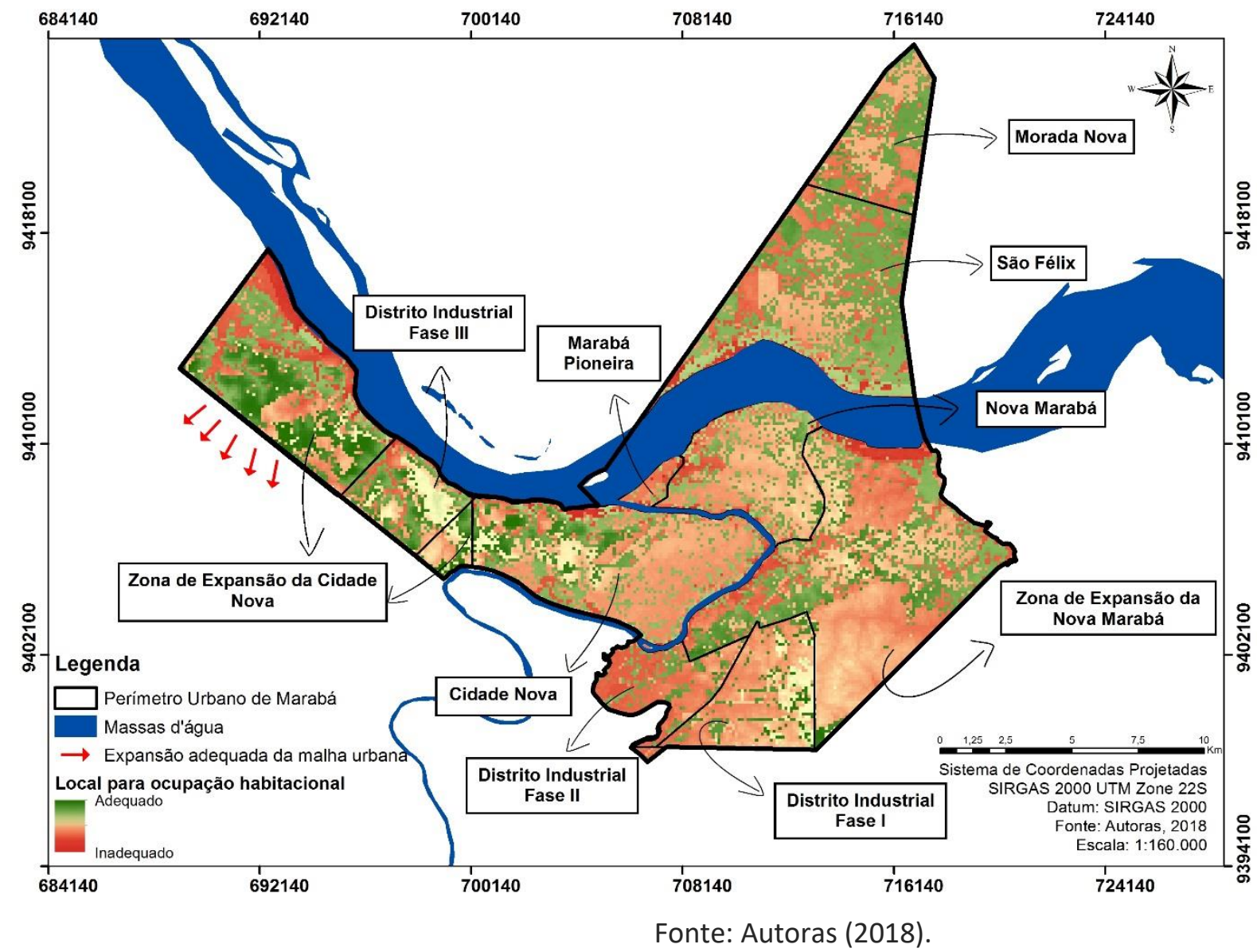

As potencialidades encontradas na Zona de Expansão da Cidade Nova, local mais adequado, se satisfazem através de uma unidade geomorfológica de baixa fragilidade, cotas altimétricas acima de 82 metros, espaços extensos com solos expostos, APP's do Rio Tocantins ainda preservadas à noroeste e fragmentos florestais em menor quantidade em relação a zona de expansão da Nova Marabá, mas que devem ser mantidos com a necessidade de constituírem corredores ecológicos.

A respeito da declividade desta zona, alguns pontos apresentam topografia acentuada e, mesmo que dentro dos limites legais de parcelamento do solo, isto é, abaixo de $30 \%$, são passíveis de planejamento adequado, uma vez que a ausência deste resulta em pavimentação de ruas paralelas a declividade e remoção da cobertura florestal. Este cenário, propõe a redução de interceptação da água da chuva, colabora para a aceleração dos fluxos dispersores de água e sedimentos, o que consequentemente, torna o terreno susceptível à processos erosivos.

Ademais, é fundamental que a expansão adequada da malha urbana seja conduzida para a região sul e sudoeste da Zona de Expansão da Cidade Nova (ver figura 9 - legenda), pois são nestas direções em que se encontram as áreas disponíveis pertencentes ao território do município de Marabá. Sendo assim, a motivação de um desenvolvimento horizontal da cidade para estes espaços livres, evita o adensamento populacional e a ocupação de APP's. Dentro desse contexto, salienta-se que tal resultado converge para o exposto por Marabá (2018), a qual 
define como diretrizes aplicáveis na Zona de Expansão da Cidade Nova, a implantação de loteamentos e condomínio, residenciais e não residenciais.

O setor leste do núcleo São Felix também é considerado adequado a habitação em virtude da presença de solos expostos, declividade e altitude favoráveis. Entretanto, a vulnerabilidade deste local se sustenta na planície fluvial, a qual é uma unidade geomorfológica fragilizada e característica de terrenos inundados. Além disto, o crescimento urbano neste setor é de certa forma limitado, posto que se situa próximo aos limites do perímetro urbano.

Embora os locais adequados se mostrem um mais favorável que o outro, ambos são espaços que se enquadram no disposto por Marabá (2006), como setores de uso controlado, os quais possuem dentre suas diretrizes a promoção da qualidade urbanísticas, recuperação de áreas de preservação, bem como impedimento de ocupação das áreas ambientalmente protegidas. Tais caminhos a serem seguidos, concatenam para o pensamento de Farias e Silva (2015), em que um ponto de equilíbrio do ambiente deve ser mantido quando usufruído um recurso natural.

Portanto, a zona de expansão da cidade nova devido ao seu potencial físico deve receber investimentos para seu planejamento e implantação de infraestrutura habitacional. Ademais, uma manutenção e recuperação da qualidade ambiental deve ser realizada nas áreas já ocupadas e no espaço urbano fragilizado que sofre estreitamento em função do rio Tocantins e sinuosidade do rio Itacaiúnas.

\section{CONCLUSÃO}

A ausência de planejamento urbano e estudos que norteiem o bom desenvolvimento das cidades em equilíbrio com o meio ambiente, torna-se a causa das diferenças sociais e da intensificação de desastres de cunho ambiental. Diante disto, o setor oeste da Zona de Expansão da Cidade Nova é o local mais adequado à ocupação habitacional. Este resultado, mostra-se compatível com o que preconiza o Plano Diretor Participativo de Marabá ao determinar a área como apta a implantação de infraestrutura urbana. Sendo assim, enfatiza-se a importância do estudo dos aspectos geoambientais paralelo ao planejamento urbano, com o intuito de minimizar a potencialização da fragilidade ambiental de áreas inapropriadas para ocupação habitacional. A partir disto, torna-se possível garantir a integridade física da população, mediante a ocorrência de eventos naturais inesperados em consonância com a conservação e preservação dos recursos naturais. 


\title{
Geo-environmental aspects as subsidy for urban planning in the city of Marabá (PA)
}

\begin{abstract}
Population growth accompanied by the urbanization process in cities has intensified occupation in increasingly densely populated areas. In this sense, the objective of this study was to evaluate the geoenvironmental aspects of the urban perimeter of Marabá-Pará to indicate areas of housing occupation. To do so, use spatial information processed by ESRI (2014), to prepare maps related to geoenvironmental aspects. After that, each geoenvironmental factor was submitted to Hierarchical Process Analysis (AHP) in the GIS environment. As a result, a compilation of data demonstrated on the urban perimeter of Marabá, $35 \%$ of the area is considered favorable in housing occupation. This percentage, a more appropriate first local option, is the western part of the Expansion Zone of Cidade Nova, where there is a predominance of appropriate areas, as they represent $57.7 \%$ of the total area. Although the São Felix nucleus is also considered suitable for housing, a vulnerability of this location is sustained in the fluvial plain, a fragile geomorphological unit and the resources of flooded land. In this sense, emphasize the importance of studying geoenvironmental aspects parallel to urban planning, in order to minimize the potentialization of environmental fragility in areas inappropriate for housing occupation.
\end{abstract}

KEY WORDS: Urbanization, physical aspects, Hierarchical Analysis of Processes. 


\section{REFERÊNCIAS}

ALBANO, M. P. A importância do planejamento urbano ambiental - a habitação social e a expansão urbana em Presidente Prudente - SP. 2013. 165 f. Dissertação (Mestrado em Meio Ambiente e Desenvolvimento Regional) - Universidade do Oeste Paulista, Presidente Prudente, 2013.

ALMEIDA, J. J. A cidade de Marabá sob o impacto dos projetos governamentais. 2008. 277 f. Dissertação (Mestrado em História Econômica) - Universidade de São Paulo, Faculdade de Filosofia, Letras e Ciências Humanas, São Paulo, 2008.

ALMEIDA, J. J. Os riscos naturais e a história: o caso das enchentes em Marabá (PA). Tempos Históricos, Paraná, v. 15, n. 2, p. 205-238, 2011.

ALVES, P. L. Capacidade de interceptação pelas árvores e suas influências no escoamento superficial urbano. 2015. 109 f. Tese (Doutorado em Ciências Ambientais) - Universidade Federal de Goiás, Goiânia, 2015.

AMARAL, R.; ROSS, J. L. S. As unidades ecodinâmicas na análise da fragilidade ambiental do parque estadual do morro do diabo e entorno, Teodoro Sampaio/SP. GEOUSP - Espaço e Tempo, São Paulo, v. 3, n. 26, p. 59-78, 2009.

BARBOSA, G. S. O desafio do desenvolvimento sustentável. Revista Visões, Macaé, v. 1, n. 4, 2008.

BARBOSA, M. E. F.; FURRIER, M.; LIMA, E. R. V. Mapeamento de adequação de uso das terras através da técnica de análise de multicritério em ambiente SIG: estudo de caso do município de Conde - PB, Brasil. Revista Colombiana de Geografía, Bogotá, v. 22, n. 1, p. 9-12, 2013.

BASTOS, F. H.; CORDEIRO, A. M. N.; SILVA, E. V. Aspectos geoambientais e contribuições para estratégias de planejamento ambiental da serra de Baturité/CE. Revista da Anpege, Rio de Janeiro, v. 13, n. 21, p. 163-198, 2017.

BRASIL. Constituição Federal. Institui a Constituição Federal. Brasília. Brasília, DF, 1988. Disponível em:

<http://www.planalto.gov.br/ccivil_03/constituicao/constituicao.htm>. Acesso em: 19 mai. 2018. 
. Lei Federal $n^{\circ} 12.651$, de 25 de maio de 2012. Dispõe sobre a proteção da vegetação nativa; altera as Leis nos 6.938, de 31 de agosto de 1981, 9.393, de 19 de dezembro de 1996, e 11.428, de 22 de dezembro de 2006; revoga as Leis nos 4.771, de 15 de setembro de 1965, e 7.754, de 14 de abril de 1989, e a Medida Provisória no 2.166-67, de 24 de agosto de 2001; e dá outras providências. Brasília, DF, 2012. Disponível em: < http://www.planalto.gov.br/ccivil_03/_ato2011-2014/2012/lei/l12651.htm>. Acesso em: 28 ago. 2018.

Lei Federal no 10.257, de 10 de julho de 2001. Regulamenta os arts. 182 e 183 da Constituição Federal, estabelece diretrizes gerais da política urbana e dá outras providências. Brasília, DF, 2001. Disponível em: <http://www.planalto.gov.br/ccivil_03/leis/LEIS_2001/L10257.htm>. Acesso em: 19 mai. 2018.

Lei Federal no 6.766:1979, de 19 de dezembro de 1979. Dispõe sobre o Parcelamento do Solo Urbano e dá outras Providências. Brasília, DF, 1979. Disponível em: <http://www.planalto.gov.br/ccivil_03/LEIS/L6766.htm>. Acesso em: 29 ago. 2018.

CABRAL, A. V. Análise multicritério em sistemas de informação geográfica para a localização de aterros sanitários: o caso da região sul da ilha de Santiago, Cabo Verde. 2012. 113 f. Dissertação (Mestrado em Gestão do Território) - Faculdade de Ciências Sociais e Humanas, Universidade Nova de Lisboa, Cabo Verde, 2012.

CAMPAGNOLO, K. Área de preservação permanente de um rio e análise do Código Florestal Brasileiro. 2013. 97 f. Dissertação (Mestrado em Engenharia Civil) - Universidade Federal de Santa Maria, Santa Maria, 2013.

CAMPOS, F. F. Análise da relação entre as Áreas de Preservação Permanente (APP's) e a qualidade da água fluvial no município de Paulínia (SP). 2011. 62 f. Trabalho de Conclusão de Curso (Graduação) - Curso de Graduação em Geologia Instituto de Geociências, Universidade Estadual de Campinas, São Paulo, 2011.

CASTRO, J. S. et al. Utilização de SIG e análise multicritério para seleção de áreas com potencial para a construção de universidades e loteamentos universitários. Boletim de Ciências Geodésicas, Curitiba, v. 21, n. 3, p. 652-657, 2015.

CHAVEZ JÚNIOR, P. S. An improved dark-object subtraction technique for atmospheric scattering correction of multispectral data. Remote Sensing of Environment, Minneapolis, v. 24, n. 3, p. 459-479, 1988. 
CONSELHO NACIONAL DO MEIO AMBIENTE - CONAMA. Resolução n 303, de 20 de março de 2002. Brasília, DF, 2002. Disponível em: <

http://www2.mma.gov.br/port/conama/res/res02/res30302.html>. Acesso em: 27 de set. 2018.

COSTA, S. S. L.; MORAES, M. V. A. R.; PORTELA, J. P. Compartimentação geoambiental do município de Demerval Lobão, Piauí. Revista de Geociências do Nordeste, Caicó, v. 1, n. 2, p. 21-37, 2015.

CREMONEZ, F. E. et al. Avaliação de impacto ambiental: metodologias aplicadas no Brasil. Revista Monografias Ambientais - REMOA, Santa Maria, v. 13, n. 5, p. 3821-3830, 2014

EMPRESA BRASILEIRA DE PESQUISA AGROPECUÁRIA - EMBRAPA. Serviço Nacional de Levantamento e Conservação de Solos. In: Reunião Técnica de Levantamento de Solos. Súmulas. Rio de Janeiro, RJ, 1979. 83 p. Disponível em: <http://library.wur.nl/isric/fulltext/isricu_i00006739_001.pdf>. Acesso em: 08 ago. 2018

ENVIRONMENTAL SYSTEM RESEARCH INSTITUTE - ESRI. ArcGis 10.2 for Desktop Help. ArcGis Professional GIS for desktop, version 10.2. 2014.

ENVIRONMENTAL SYSTEM RESEARCH INSTITUTE - ESRI. ArcGis Professional GIS for desktop, version 10.2. 2014.

EXELIS VISUAL INFORMATION SOLUTIONS - EXELIS. Envi, version 5.1. 2013.

FARIAS, J. F.; SILVA, E. V. Compartimentação geomorfológica da Bacia Hidrográfica do Rio Palmeira-Ceará: subsídios ao Planejamento Ambiental. Geosaberes, Fortaleza, v. 6, n. spe, p. 149-163, 2015.

FONTOURA, L. N. J. Planejamento urbano-ambiental: o uso e ocupação do solo no Distrito Federal. Revista Especialize, Goiânia, v. 1, n. 5, 2013.

FREITAS, V. A. L.; BASSO, L. O.; FERRI, R. Sensoriamento Remoto e Geoprocessamento. Pato Branco: UTFP, 2015. 37 p.

FURTADO, A. M. M.; PONTE, F. C. Mapeamento de unidades de relevo do Estado do Pará. Revista GeoAmazônia, Belém, v. 02, n. 2, p. 56-67, 2013. 
GOMES, M. A. F.; PEREIRA, L. C. Aspectos geoambientais e áreas frágeis no Brasil. Revista Intellectus, Jaguariúna, v. 1, n. 26, p. 5-19, 2014.

HAMADA, E.; GONÇALVES, R. R. V. Introdução ao geoprocessamento: princípios básicos e aplicação. 1. ed. São Paulo: Embrapa e Meio Ambiente, 2007. 52 p.

HONDA, S. C. A. L. et al. Planejamento ambiental e ocupação do solo urbano em Presidente Prudente (SP). Revista Brasileira de Gestão Urbana, Paraná, v. 7, n. 1, p. 62-73, 2015.

IELO, E. M. Estudo de Vulnerabilidade à Inundação no Município de Ourinhos (SP). 2015. 88 f. Dissertação (Mestrado em Geografia) - Universidade Estadual Paulista Júlio de Mesquita Filho, Ourinhos, 2015.

INSITUTO BRASILEIRO DE GEOGRAFIA E ESTATÍSTICA - IBGE. População estimada: IBGE, Diretoria de Pesquisas, Coordenação de População e Indicadores Sociais, Estimativas da população residente com data de referência 1 o de julho de 2018. Brasília, jul. 2018. Disponível em:

$<$ https://cidades.ibge.gov.br/brasil/pa/maraba/panorama>. Acesso em: 13 de jul. 2018.

INSTITUTO BRASILEIRO DE GEOGRAFIA E ESTATÍSTICA - IBGE. Domínio Morfoestrutural e Unidade Geomorfológica da Amazônia Legal. Rio de Janeiro: Diretoria de Geociências - Geoserviços, 2018. Escala 1:250.000. Disponível em: $<$ http://dados.gov.br/dataset/cren_formapoligonalgeomorfologicaamazonialegal _250>. Acesso em: 19 abr. 2018.

MARABÁ. Lei Municipal n 17.846, de 29 de março de 2018. Dispõe sobre a revisão do Plano Diretor Participativo do município de Marabá, instituído pela Lei Municipal $n^{\circ} 17.213$ de 09 de outubro de 2006, e dá outras providências. Marabá, PA, 2018. Disponível em: < http://www.governotransparente.com.br/transparencia/documentos/4466490/d ownload/29/Plano_Diretor_Participativo_\%2017.846_Mar\%C3\%A7o_2018.pdf >. Acesso em: 27 de set. 2018.

Lei Municipal no 17.213, de 09 de outubro de 2006. Institui o Plano Diretor Participativo do Município de Marabá. Marabá, PA, 2006. Disponível em: <http://www.seidurb.pa.gov.br/pdm/maraba/pdm.pdf>. Acesso em: 12 abr. 2017.

. Lei Municipal no 17.358 de 03 de julho de 2009. Dá nova redação ao art. perímetro urbano do Município de Marabá. Marabá, PA, 2009. Disponível em: 
<http://www.maraba.pa.leg.br/consultas/leis-municipais>. Acesso em: 12 abr. 2017.

MARINONE, O. Implementation of the analytical hierarchy process with VBA in ArcGIS. Computers \& Geosciences, United Kingdom, v. 30, n. 6, p. 637-646, 2004.

MARTINI, A.; BIONDI, D. Microclima e conforto térmico de um fragmento de floresta urbana em Curitiba, PR. Floresta e Ambiente, Rio de Janeiro, v. 22, n. 2, p. 182-193, 2015. Disponível em:<http://www.scielo.br/pdf/floram/v22n2/21798087-floram-22-2-182.pdf >. Acesso em: 28 de set. 2018.

MASCARENHAS, A. L. S.; VIDAL, M. R. Declividade e Hipsometria do Perímetro urbano da cidade de Marabá-PA: aportes conceituais de geomorfologia urbana. In: CONGRESSO BRASILEIRO DE GEÓLOGOS, 7, 2014, Vitória, ES. Anais... Vitória, CBG, 2014, p. 1-11.

MINISTÉRIO DO MEIO AMBIENTE - MMA. Instrumento de Planejamento. Disponível em: <http://www.mma.gov.br/cidades-sustentaveis/planejamentoambiental-urbano/item/8057>. Acesso em: 21 mai. 2016.

MONTEIRO, T. C. Construções em Áreas de Preservação Permanente e o conflito entre direitos fundamentais. Revista Eletrônica do Curso de Direito da UFSM, Santa Maria, v. 7, n. 2, p. 113-132, 2012. Disponível em: <https://periodicos.ufsm.br/revistadireito/article/view/7526/pdf >. Acesso em: 26 set. 2018.

OLIVEIRA, F. G.; SERAPHIM, O. J.; BORJA, M. E. L. Estimativa de perdas de solo e do potencial natural de erosão da bacia de contribuição da microcentral hidrelétrica do Lageado, Botucatu - SP. Revista Energia na Agricultura, Botucatu, v. 30, n. 3, p. 302-309, 2015.

PARÁ. Secretaria de Estado de Desenvolvimento Econômico, Mineração e Energia (SEDEME). Relatório de impacto ambiental - RIMA da Ferrovia Paraense S.A: Diagnóstico Ambiental (meio físico). Pará, 2017. 246 p.

PINESE JÚNIOR, J.; RODRIGUES, S. O método de Análise Hierárquica - AHP como auxílio na determinação da vulnerabilidade ambiental da bacia hidrográfica do rio piedade (MG). Revista do Departamento de Geografia, São Paulo, v. 23, n. 1, p. 4-26, 2012. 
RUSSI, A. Entre o legal e o real: a regularização fundiária nos assentamentos urbanos informais do município de Marabá. 2014. 118 f. Dissertação (Mestrado em Dinâmicas Territoriais e Sociedade na Amazônia) - Universidade Federal do Sul e Sudeste do Pará, Marabá, 2014.

SAATY, T. L. Decision making for leaders: The Analytic Hierarchy Process for Decisions in a Complex World. Pittsburg, USA: WS. Publications, 2000.

Relative measurement and its generalization in decision making why pairwise comparisons are central in mathematics for the measurement of intangible factors the analytic hierarchy/network process. Rev. R. Acad. Cien. Serie A. Mat. - RACSAM, Madrid, v. 102, n. 2, p. 251-318, 2008.

The Analytic Hierarchy Process: Planning, priority setting, resource allocation. New York, USA: McGraw-Hill, 1980.

SCHAADT, S. S.; VIBRANS, A. C. O uso da terra no entorno de fragmentos florestais influencia a sua composição e estrutura. Floresta e Ambiente, Rio de Janeiro, v. 22, n. 4, p. 437-445, 2015. Disponível em: < http://www.scielo.br/pdf/floram/v22n4/2179-8087-floram-21798087062813.pdf>. Acesso em: 28 de set. 2018.

SCHUTZER, J. G. Análise estratégica do relevo e planejamento territorial urbano: compartimentos ambientais estruturantes na macrometrópole de São Paulo. Revista LABVERDE, São Paulo, v. 1, n. 5, p. 12-36, 2012.

SECRETARIA MUNICIAPAL DE PLANEJAMENTO - SEPLAN. Marabá: Diretoria do Plano Diretor Participativo, 2018. Escalas variam.

SILVA, C. R.; DANTAS, M. E. Mapas Geoambientais. In: SIMPÓSIO BRASILEIRO DE CARTOGRAFIA GEOTÉCNICA E GEOAMBIENTAL, 7, 2010, Maringá, PR. Anais... Maringá, SBCGG, 2010, p. 1-17.

SILVA, T. I.; RODRIGUES, S. C. Tutorial de cartografia geomorfológica: ArcGis 9.2 e Envi 4.0. Rev. Geogr. Acadêmica, Boa Vista, v. 3, n. 2, p. 85-94, 2009.

SMITH, R. B. Tutorial Image Classification. 1. ed. Nebraska: Microlmages Inc., 2011. 35 p.

SOUSA, S. B.; OLIVEIRA, I. J. A compartimentação do relevo como ferramenta para o planejamento ambiental urbano: uma análise da bacia hidrográfica do córrego pedreira, município de Goiânia (GO). Ateliê Geográfico, Goiânia, v. 5, n. 1, p. 135-161, 2011. 
TRAVALINI, V.; CUNHA, C. M. L.; Análise da declividade do terreno do município de Bertioga-SP e sua relação com os compartimentos geomorfológicos. In: SIMPÓSIO BRASILEIRO DE GEOMORFOLOGIA, 8, 2010, Recife, PE. Anais... Recife, SINAGEO, 2010, p. 1-16.

UNITED STATES GEOLOGICAL SURVEY - USGS. Imagem do satélite Sentinel. United States: Earth Explorer, 2018. Disponível em: <https://earthexplorer.usgs.gov/>. Acesso em: 17 mar. 2018.

UNITED STATES GEOLOGICAL SURVEY - USGS. Modelo Digital de Elevação. United States: Earth Explorer, 2014. Disponível em: <https://earthexplorer.usgs.gov/>. Acesso em: 17 mar. 2018.

VALENTE, R. O. A.; VETTORAZZI, C. A. Comparação entre métodos de avaliação multicriterial, em ambiente SIG, para a conservação e a preservação florestal. Scientia Forestalis, Piracicaba, v. 3, n. 69, p. 51-61. 2005.

VIDAL, M. R.; MASCARENHAS, A. L. S. Paisagens do município de Marabá a partir de uma visão geossistêmica. In: CONGRESSO NACIONAL DE GEOGRAFIA FÍSICA, 1, 2017, Campinas, SP. Anais... Campinas, CNGF, 2017, p. 4417-4425.

Recebido: 30 nov. 2019

Aprovado: 28 jan. 2020

DOI: $10.3895 /$ rbpd.v9n2.9021

Como citar: COSTA S. T. L.; FARIAS, L. J. S.; LOUREIRO, G. E. Aspectos geoambientais como subsídio ao planejamento urbano da cidade de Marabá (PA). R. bras. Planej. Desenv. Curitiba, v. 9, n. 2, p. 257-284 mai./ago. 2020. Disponível em: <https://periodicos.utfpr.edu.br/rbpd>. Acesso em: XXX.

Correspondência:

Savannah Tâmara Lemos da Costa

Avenida Hiléia, s/n - Agrópoles do Incra - Marabá, PA

Direito autoral: Este artigo está licenciado sob os termos da Licença CreativeCommons-Atribuição 4.0

Internacional.

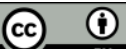

